\title{
Kaseta Stanisława Wyspiańskiego z motywami lilii w zbiorach Muzeum Uniwersytetu Jagiellońskiego
}

\section{ABSTRACT}

Stanislaw Wyspianski's casket with a lily motifs in the collection of the Jagiellonian University Museum

The Museum holds a number of paintings and drawings by Stanislaw Wyspianski. As well as that, there are two interesting functional objects complementing the collection: a quill pen used by the poet to write 'November Night' finished in 1904, secured with great care by Tadeusz Estreicher, and a casket made by Wyspianski. The pen used by the poet is of sentimental value only, although the casket, which he made for his wife, has kept its practical value, and proves the artist's interest in the craftwork.

Keywords: casket, Wyspiański, lilies

Słowa kluczowe: kaseta, Wyspiański, lilie

Muzeum posiada dzieła malarskie i rysunkowe Stanisława Wyspiańskiego. Obok nich poczesne miejsce znalazły interesujące dwa przedmioty użytkowe, które wzbogaciły zbiór pamiątek: gęsie pióro ${ }^{1}$, którym poeta pisał Noc listopadowa pieczołowicie

${ }^{1}$ Pokazane na wystawach: „, Silva Rerum”. Pamiątki akademickie ze zbiorów Muzeum Uniwersytetu Jagiellońskiego. Katalog wystawy, Collegium Maius XII 1997 - I 1998, autor wstępu do katalogu i biogramów A. Piskorz, przedm. S. Waltoś [Kraków] 1998, kat. V/22 (oprac. hasła: A. Piskorz); Piękno darowane. Dzieła ofiarowane Uniwersytetowi Jagiellońskiemu w zbiorach Collegium Maius. Katalog wystawy zorganizowanej w Collegium Maius Uniwersytetu Jagiellońskiego w dniach 7 maja-6 sierpnia 2014 roku z okazji jubileuszu 650-lecia uczelni, red. J. Pollesch, M. Zdanek, Kraków 2014 (oprac. hasła M.N. Gajek), s. 252. 
zabezpieczone przez prof. Tadeusza Estreichera, oraz zdobioną przez Wyspiańskiego kasetę $^{2}$, przeznaczoną dla żony. O ile pióro używane przez poetę ma jedynie wartość sentymentalną, o tyle kaseta, zachowując tę wartość, jednocześnie potwierdza, że Wyspiański, zgodnie z morrisowską ${ }^{3}$ koncepcją integracji sztuki i rzemiosła:

(...) nie tylko projektował, ale bezpośrednio uczestniczył w procesie realizacji swoich pomysłów dokładnie zaznajamiając się z technikami rzemieślniczymi, i właściwościami tworzywa, które respektował jako immanentne składniki ostatecznej formy i artystycznej wymowy dzieła ${ }^{4}$.

Kaseta z malowanymi motywami białych lilii powstała w wyniku współpracy artysty i rzemieślnika5 . Wyspiański sporządził projekt drewnianej kasety, a w końcowym etapie prac - malaturę na gotowym przedmiocie. Wykonanie samego przedmiotu, powierzył pracowni Andrzeja Sydora, który od roku 1903 realizował jego projekty meblarskie ${ }^{6}$.

${ }^{2}$ Kaseta (fr. cassette, wł. cassetta) skrzynka, pudełko z wieczkiem, szkatułka. Sam Wyspiański używa określenia: kaseta (w projekcie) lub kasetka [S. Wyspiański, Listy zebrane, t. 4: Listy różne do wielu adresatów, t. 4, teksty listów oprac. i komentarz M. Rydlowa, z wykorzystaniem materiałów L. Płoszewskiego, Kraków 1998, s. 376]. Prof. Karol Estreicher określił kasetę jako „skrzynkę na listy" - prawdopodobnie słyszał o takim jej przeznaczeniu. Vide K. Estreicher, Collegium Maius i zbiory Muzeum Uniwersytetu Jagiellońskiego, Kraków 1967, s. 110; idem, Muzeum Uniwersytetu Jagiellońskiego, Warszawa, Kraków 1980, s. 150.

${ }^{3}$ William Morris (1834-1896) angielski teoretyk sztuki, projektant, architekt, poeta i pisarz, współtwórca Arts and Crafts Movement, pozostający pod wpływem idei artystycznych prerafaelitów, odegrał wielką rolę w ruchu odnowy rzemiosła artystycznego i sztuk użytkowych, przeciwstawiając się masowej produkcji fabrycznej.

Wyspiański „,całą swoją twórczością realizował ideał artysty-rzemieślnika, który nie dzieli sztuk na piękne i stosowane, co było realizacją ideałów Arts and Crafts Movement. Taka postawa zakładała integralny związek rzemiosła artystycznego i malarstwa, czego petryfikacją była twórczość prerafaelitów”. A. Szczerski, Wzorce tożsamości. Recepcja sztuki brytyjskiej w Europie Środkowej około roku 1900, Kraków 2002, s. 114.

${ }^{4}$ A. Sieradzka, Stanisław Wyspiański jako prekursor stylu Art Déco w polskim rzemiośle artystycznym [w:] Rzemiosto artystyczne. Materiały Sesji Oddziatu Warszawskiego Stowarzyszenia Historyków Sztuki, red. R. Bobrow, Warszawa 1996, s. 131.

${ }^{5}$ Zainteresowania Wyspiańskiego obejmowały nie tylko rzemiosło, ale także rzemieślnicze narzędzia, które utrwalił w rysunkach: imadła ślusarskiego i stolarskiego warsztatu; J. Güttler, Stanisław Wyspiański (1869-1907). Obrazy i rysunki ze zbiorów lwowskich. Wystawa urzq̨dzona ku uczczeniu 25-tej rocznicy zgonu artysty, listopad-grudzień 1932, Lwów 1932, s. 10, poz. 47/a, poz. 47/b.

${ }^{6}$ Wyspiański notował kolejne adresy stolarza. W liście: „Andrzej Sydor (ul. Długa)” [S. Wyspiański, Listy zebrane, t. 4..., s. 194] i w Raptularzu z 1905 roku: „ulica Bogata” [ibidem, s. 410; wg Czecha: „przecznica między ulicą Karmelicką a Stachowskiego tak zwana Bogata”, której wszystkie realności należały do gminy Czarna Wieś, Kalendarz Krakowski Józefa Czecha na rok 1905, s. 321]. O meblach na Wystawę Jubileuszową Towarzystwa Artystów Polskich „Sztuka” zorganizowaną w Pałacu Sztuki oraz do mieszkania Żeleńskich projektowanych w 1904 roku i wykonanych w pracowni Sydora - m.in. w: „Sztuka Stosowana" 1907, z. 10, s. 35-38; A. Sieradzka, op. cit., s. 131-143; Wyspiański. Katalog wystawy dziet ze zbiorów Muzeum Narodowego w Krakowie, red. D. Godyń, M. Laskowska, Kraków 2017. Z początkiem marca 1905 roku podziwiano wystrój wnętrz Towarzystwa Lekarskiego; prasa podawała: „roboty stolarskie wykonała "pracownia p. Sydora«" [„Nowa Reforma”, 3.03.1905, nr 51, s. 3]. W następnym roku u Sydora powstały także meble do ekspozycji Muzeum Katedralnego na Wawelu [J. Urban, Muzeum Katedralne na Wawelu, „, Muzealnictwo” 2008, nr 49, s. 115]. Po śmierci Wyspiańskiego Sydor pracował dla 
Wiadomo, że Sydor wywiązał się z przyjętego zlecenia i po tygodniu, Wyspiański mógł odnotować: „Sydor oddaje kasetki zapuszczone czarno, maluję tło błękitne”7, a dzień później: „Rano maluję lilie na kasecie”.

We wspomnieniach osób, które znały Wyspiańskiego, powtarza się opinia o jego wielkim umiłowaniu kwiatów, co z czasem zaowocowało powstaniem ,Zielnika” i stylizacji do dzieł malarskich, grafiki i rzemiosła. Jeszcze jako uczeń: „wracając ze szkoły szedł Plantami i wracał do domu spóźniony z bukiecikiem kwiatów, które zbierał na Plantach"; jako dorosły „wychodził (...) często na dalekie, samotne spacery, na Bielany, i wracał z pękami kwiatów rwanych w całości, i ozdabiał nimi swoją pracownię"10. W liście do Lucjana Rydla Wyspiański pisał: „Nie mogę się doczekać kwiatów i wiosny i wyobrażam sobie już moje szaleństwa jak cały pokój będzie pełny woni i barw zielska, zieloności, chwastów"11. Przyjaciele przynosili mu kwiaty na stół do pracowni w mieszkaniu przy ul. Krowoderskiej. Prof. Michał Siedlecki zapamiętał, że „Często na tym stole stały kwiaty w wazoniku, przeważnie polne"'12. Alfred Nowaczyński tak wspominał reakcję Wyspiańskiego na przynoszone kwiaty: „Gdy się (...) wchodziło np. z malwami, nagietkami, z „,»pantofelkami Matki Boskiej « ${ }^{13}$, z kiściami serduszek różowych - twarz surowa za pukanie intruza rozpromieniała się cudownie (...). W kwiaty mógł wpatrywać się godzinami"'14. W notatkach Antoniego Godziemby Wysockiego odwiedzającego artystę znalazła się uwaga: „Na stole bieliły się kartony rysunków, przedstawiających

innych artystów. M.in. w 1909 roku jego pracownia wykonała komplet mebli wg projektu Karola Tichego do konkursu ogłoszonego przez Miejskie Muzeum Techniczno-Przemysłowe w Krakowie [,,Sztuka Stosowana” 1909, z. 13, s. 63-65]. W 1910 roku firmę anonsowano: „Artystyczna pracownia stolarska Andrzeja Sydora w Krakowie przy ul. Ambrożego Grabowskiego 1.9 wykonuje wszelkie roboty w zakres stolarstwa wchodzące według projektów własnych lub wskazanych. Zakład odznaczony został I-szą nagrodą na fachowym konkursie Muzeum przemysłowego, jako też uzyskał liczne wyrazy uznania zamieszczone wielokrotnie w czasopismach polskich” [„Nowa Reforma”, 14.05.1910, nr 217, s. 5]. W 1911 roku Sydor został powołany na członka komisji do wystawy współczesnej sztuki kościelnej jako jeden z dwóch przedstawicieli rękodzieła krakowskiego [„Krakowski Miesięcznik Artystyczny”, 1.07.1911, nr 6, s. 71]. Podobnie w marcu 1918 roku jako reprezentant ,przemysłowców stolarskich” zasiadał w sądzie konkursu „,na projekt mebli włościańskich i małomieszczańskich”, ogłoszonego przez Biuro przemysłu drzewnego c.k. namiestnictwa (C.O.G.) i Wydziału krajowego [„Czas”, 2.03.1918, nr 101, s. 2].

7 S. Wyspiański, Raptularz, notatka z 28 IX 1904 roku [w:] idem, Listy zebrane, t. 4..., s. 376.

${ }^{8}$ Idem, Raptularz, notatka z 29 IX 1904 roku [w:] idem, Listy zebrane, t. 4 ..., s. 376.

${ }^{9}$ P. Mączewski, Notatki z rozmów z Janina Stankiewiczowa [w:] Wyspiański w oczach wspótczesnych, zebrał, oprac. i komentarz L. Płoszewski, t. 1, Kraków 1971, s. 26.

${ }^{10}$ F. z Waśkowskich Mrozicka, Zżycia Wyspiańskiego [w:] Wyspiański w oczach współczesnych..., t. 1, s. 44 .

${ }^{11}$ S. Wyspiański, List z 19 I 1896 roku [w:] idem, Listy zebrane, t. 2: Listy Stanisława Wyspiańskiego do Lucjana Rydla, cz. 1: Listy i notatnik z podróży, teksty listów oprac. L. Płoszewski, M. Rydlowa, Kraków 1979, s. 291.

${ }_{12}$ M. Siedlecki, Wspomnienia o Wyspiańskim i Reymoncie [w:] Wyspiański w oczach współczesnych..., t. 2, s. 195.

${ }^{13}$ Roślina trująca: Tojad Aconitum L., zwana „pantofelkami Matki Boskiej”, o trzewiczkowatych w kształcie niebieskich lub ciemnofioletowych kwiatach. J. Mowszowicz Przewodnik do oznaczania krajowych roślin zielarskich, wyd. 2, Warszawa 1985, s. 59.

${ }^{14}$ A. Nowaczyński, Wyspiander (Moje wspomnienia) [Wyjątki] [w:] Wyspiański w oczach wspótczesnych..., t. 1, s. 423. 
kwiaty (...). Same kwiaty i kwiaty"15. Rysunki Wyspiańskiego docenił także botanik prof. Władysław Szafer, który kilkakrotnie wypowiadał się na temat jego „Zielnika” ${ }^{16}$.

Jak już wspomniano, w płycinach kasety zostały rozmieszczone białe lilie. Kwiaty te zawsze wzbudzały zachwyt Wyspiańskiego. Latem 1890 roku podczas pobytu we Francji Wyspiański nie tylko podziwiał gotycką architekturę i zbiory muzealne, ale poza miastem z wielką uwagą przyglądał się występującym tam roślinom. W listach do Lucjana Rydla widać tyle samo zainteresowania dla sztuki co dla pełnej nieocenionych form natury. W liście z Chartres pisał m.in. o wydarzeniu w drodze z Caudebec-en-Caux do Lillebonne: „Zerwałem gdzieś w jakimś ogrodzie parę lilii - na co - chciałem dać komuś te kwiaty... komuż - jakaś maleńka dziewczynka - bawiła się przy drodze (...) - dałem jej te lillowe kielichy" "17. Urzeczony pięknem architektury katedry w Reims i zasłuchany w muzykę katedralnych dzwonów Wyspiański dał się ponieść wyobraźni. W kolejnym liście, z Reims, pisząc do przyjaciela, w poetyckie opisy architektury wplata wyobrażenia średniowiecznych jeźdźców: „,każdego zbroja migoce cennym blaskiem złota - na tarczach połyskują lilie białe; w rękach ich berła rozkwitają białych lilii kielichem; korony na ich głowach utkane z kwiecia niewinności, z lilii białych" "18. W jego myślach snują się ,,jakieś ballady, które wszystkie wydają się prawdą: o jakimś gronie rycerzy dumnych i ich królu"; Wyspiański wyobraża sobie nieszczęśliwą miłość królewny i pasterza, „którzy stroili się razem w polnych kwiatów korony”, a także króla, który zapomniał o miłości i skrwawił „serce dziewczęciu jak lilii białą koronę"19. Nawet dźwięk katedralnego dzwonu łączy się z personifikacją roślin: ,głos dzwonu biegł daleko na pola... wsłuchiwały się w niego kwiaty i tuląc do siebie główki, szeptały historie miłości dwojga kochanków - uśmiechały się bławatki - rumieniły lilie białe"20.

Ciesząca się estymą biała lilia (Lilium candidum L.) była już w IX stuleciu, w epoce Karola Wielkiego, jedną z roślin leczniczych zalecanych do sadzenia w ogrodach królewskich i przyklasztornych ,,hortulusach”, ogródkach ziołowych ${ }^{21}$. Uważana w Bibliii ${ }^{22}$ za najpiękniejszy z kwiatów, o złożonej symbolice, wielokrotnie występuje w ikonografii

${ }^{15}$ A. Godziemba Wysocki, Ze wspomnień o Wyspiańskim [W skróceniu] [w:] Wyspiański w oczach wspótczesnych..., t. 1, s. 479.

${ }^{16}$ M.in. porównał „Zielnik” do renesansowych prac Hansa Weiditza II (ok. 1495-1536) ilustratora Herbarium Vivae Eicones Otto Brunfelsa. „Zielnik” wg Szafera: , jest to zbiór ołówkowych rysunków roślin, wykonany w naturze, a następnie podmalowany tu i ówdzie akwarelą dla utrwalenia w pamięci artysty subtelnych odcieni barw kwiatów i liści (...), lepszych, to znaczy wierniejszych i piękniejszych rysunków roślin, nikt nigdy w Polsce dotychczas nie wykonał (...)", S. Wyspiański, Listy zebrane, t. 2: Listy Stanistawa Wyspiańskiego do Lucjana Rydla, cz. 2: Dodatek krytyczny, napisali L. Płoszewski, M. Rydlowa, Kraków 1979, s. 189.

${ }^{17}$ S. Wyspiański, Listy zebrane, t. 2, cz. 1..., s. 84-85.

18 Ibidem, s. 130.

${ }^{19}$ Ibidem, s. 138-139.

${ }^{20}$ Ibidem, s. 140.

${ }^{21} \mathrm{~W}$ starożytności znany był olejek liliowy stosowany na przypadłości niewieście oraz choroby skóry i reumatyzm. M.J. Kawałko, Historie ziołowe, Lublin 1986, s. 41, 92-95.

22 Vide Pierwsza Księga Królewska 7, 20, 7, 22, 7, 26; Druga Księga Kronik 4, 5; Księga Psalmów

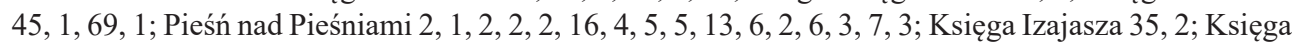
Ozeasza 14, 6 ; Ewangelia wg św. Mateusza 6, 28; Ewangelia wg św. Łukasza 12:27 [w:] Pismo Święte Starego i Nowego Testamentu, Biblia Tysiaclecia, w przekładzie z języków oryginalnych opracował 
chrześcijańskiej, obrazując m.in. czystość, nieskalaną dziewiczość, bezgrzeszność, szlachetność duszy ${ }^{23}$.

W latach 1895-1897 Wyspiański często rysował lilie w związku z powierzeniem mu wykonania projektów polichromii i witraży do kościoła Franciszkanów w Krakowie. W transepcie Wyspiański umieścił fryz z białych lilii ${ }^{24}$, w prezbiterium motywy lilii w jednym ze szlaków kwiatowych ujmujących wizerunek Matki Boskiej („Maryjki”, jak Ją nazywał $)^{25}$ z Dzieciątkiem, a w witrażu błogosławionej Salomei wkomponował lilie w górnych jego kwaterach ${ }^{26}$. Planował także oświetlenie kościoła świecznikami własnego pomysłu. Szczęśliwie zachowany projekt świecznika, ,którego kształt doszczętnie tonie w gąszczu kwiatów lilij" ${ }^{27}$, oraz rysunki jego detali przechowuje Muzeum Narodowe w Krakowie ${ }^{28}$. Wiele niezrealizowanych pomysłów znamy jedynie z rysunków, m.in. z krakowskiej kolekcji dr Bernarda Steinberga, obejmujących projekty kielichów, w których Wyspiański wkomponował motywy kwiatowe, także lilie ${ }^{29}$. Mając za sobą prace nad studiami kwiatów do polichromii i witraży, Wyspiański poszedł w ślady Williama Morrisa i zajął się również grafiką książkową oraz typografią. Jak pisze Tymon Niesiołowski: „Rysunkowi oddał pierwszeństwo. Linia w znaczeniu dekoracyjnym absorbowała go całkowicie. W linii leżała cała poezja jego prac" ${ }^{30}$. Jego dokonania dostrzeżono i właści-

zespół biblistów polskich z inicjatywy benedyktynów tynieckich, red. o. A. Jankowski OSB, ks. L. Stachowiak (ST), ks. K. Romaniuk (NT), wyd. 2 zmien., Poznań, Warszawa 1971.

23 Jako kwiat symbolizujący łaskę występuje w przedstawieniach Chrystusa Sędziego [Sąd Ostateczny Hansa Memlinga], a jako kwiat maryjny towarzyszy wizerunkom Matki Boskiej w scenach zwiastowania czy Madonny Apokaliptycznej [obraz z kościoła Matki Bożej Różańcowej w Przydonicy, ok. 1450-1460]. Pojawia się w wizerunkach Matki Boskiej Królowej, zarówno w ujęciu heraldycznym, jak i realistycznym [Madonna w kameryzowanej koronie, z wetkniętymi żywymi kwiatami, m.in. lilii, w obrazie z ołtarza gandawskiego Jana van Eycka]. Biała lilia jest także atrybutem wielu świętych.

${ }^{24}$ O szczegółach realizacji dzieła wspomina Adam Chmiel: „Malarzowi, który według kartonów miał wykonać malowanie na ścianie, dawał Wyspiański oprócz rysunku kolorowego jeszcze tony barw według numerów, pod jakimi w wykazach fabrycznych były umieszczone. Mam np. objaśnienie takie do polichromii (...) Lilie: kwiat 2, pręciki 50, tło 40, przestrzeń 54, złota struna 65, rąbek brąz". A. Chmiel, Nieco ze wspomnień o Stanisławie Wyspiańskim (1869-1907) [w:] Wyspiański w oczach wspótczesnych..., t. 2, s. 150-151.

${ }^{25}$ S. Wyspiański, List z 19 I 1896 roku [w:] idem, Listy zebrane, t. 2, cz. 1..., s. 290. Muzeum Narodowe w Krakowie posiada projekty polichromii (1895 rok) i przepruchę motywu lilii, a także fotografie Juliusza Miena dokumentujące efekt ukończonych prac Wyspiańskiego. Vide Wyspiański. Katalog wystawy..., s. 86, 132-133.

${ }^{26}$ Projekty witraży (1897 rok) zachowały się w Muzeum Narodowym w Krakowie, Wyspiański. Katalog wystawy..., s. 151. Muzeum Narodowe w Warszawie posiada „Zielnik” Wyspiańskiego, który zawiera m.in. rysunek rośliny określonej przez autora jako: „Lilia cmentarna” (wł. Liliowiec rudy, Hemerocallis fulva; vide http://cyfrowe.mnw.art.pl/dmuseion/docmetadata?id=11843). Wyspiański rysował ową lilię 28 czerwca 1896 roku w ogrodach oo. dominikanów. Motywu liliowca użył potem do kompozycji kwiatowej w kartonie witraża Żywioł ognia (II). Wyspiański. Katalog wystawy ..., il. III 5.

${ }^{27}$ T. Seweryn, Indywidualność plastyczna Wyspiańskiego, „Rzeczy Piękne” 1932, R. 11, nr 1-12, s. 28.

28 Wyspiański. Katalog wystawy..., s. 75, 129.

29 Stanisław Wyspiański: dzieła malarskie, tekst S. Przybyszewski, T. Żuk Skarszewski, indeks oprac. S. Świerz, Bydgoszcz 1925, s. 124, poz. 462-465; T. Seweryn, op. cit., s. 21.

${ }^{30}$ T. Niesiołowski, [Z tomu wspomnienia] [w:] Wyspiański w oczach współczesnych ..., t. 2, s. 429. 


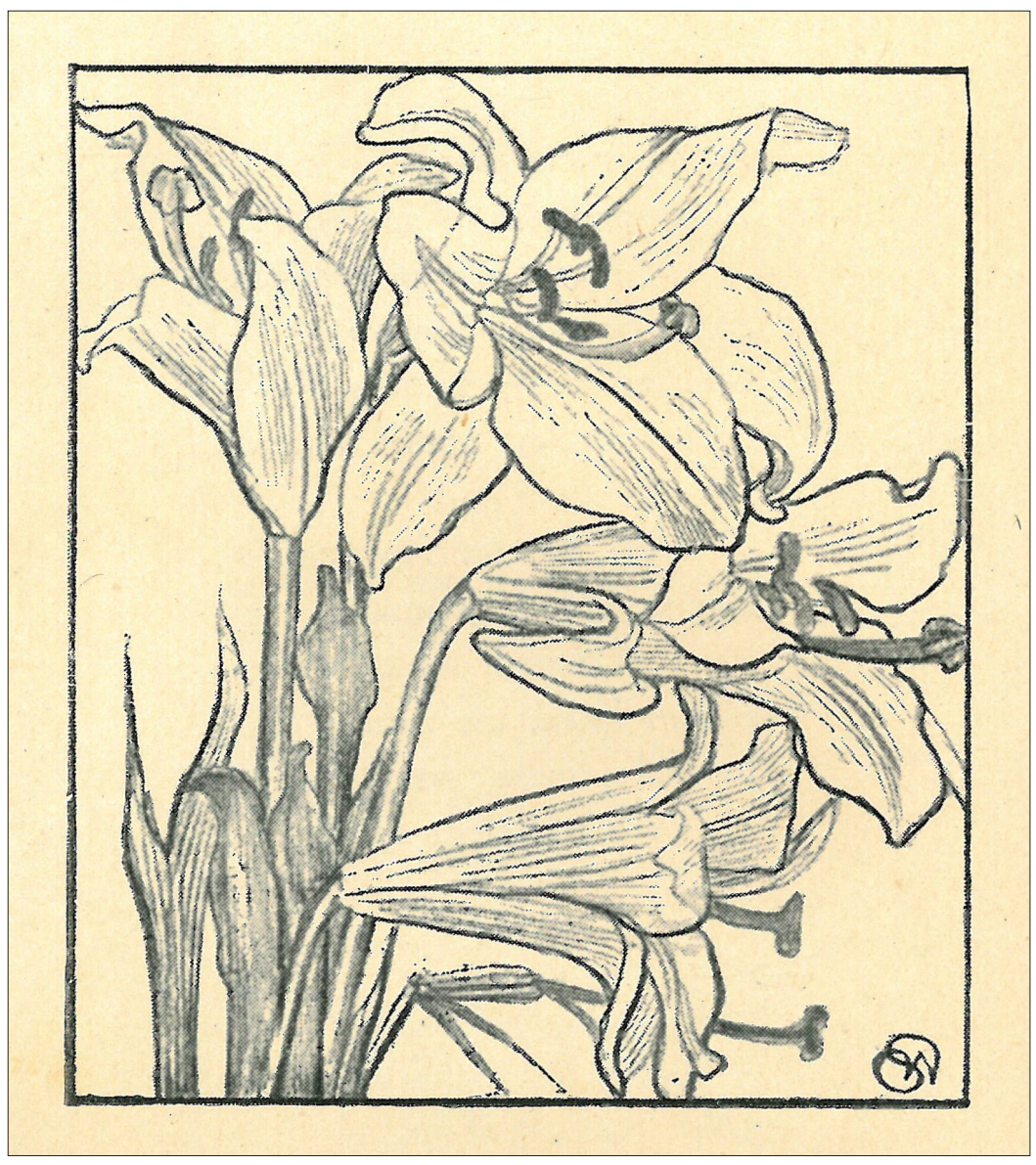

Il. 1. Stanisław Wyspiański, winieta „Lilie” [w:] L. Rydel, Poezye I. Z rysunkami Stanisława Wyspiańskiego, Gebethner i Wolff, G. Gebethner i Spółka, Warszawa, Kraków 1899, s. 52. Fot. Biblioteka Jagiellońska

wie oceniono: ,zdobnictwo Wyspiańskiego jest zawsze pełne umiaru i prostoty, a motyw każdy jest zwykle przestudiowany i opracowany tak, że stanowi czysty ornament " ${ }^{\prime 1}$. W liście do Lucjana Rydla Wyspiański złożył serdeczną w tonie ofertę: „gdy będziesz wydawał twój tomik, pragnąłbym go ozdobić ornamentami mojemi i marginesami strojnymi. Myślę, że mi nie odmówisz tej przyjemności”’32. I ozdobił, tworząc winiety i przerywniki przeniesione potem na klisze drukarskie. Alfred Wysocki dobrze zapamiętał owe klisze: „gotowe klisze przepięknych wówczas nigdzie nie spotykanych motywów kwiatowych, liści klonowych, lilii, ostu (...), które miały swój oryginalny styl”33. Wcześniej jednak, w czerwcu 1898 roku, wybrane z nich motywy (m.in. winieta

${ }^{31}$ P. Smolik, Książka Stanisława Wyspiańskiego, „Rzeczy Piękne” 1932, R. 11, nr 1-12, s. 37.

32 S. Wyspiański, List z Krakowa, 19 I 1896 roku [w:] idem, Listy zebrane, t. 2, cz. 1.., s. 290.

${ }^{33}$ Alfred Wysocki, korektor w krakowskim „Czasie”. A. Wysocki, [Z pamiętników „Sprzed pót wieku”] [w:] Wyspiański w oczach wspótczesnych..., t. 1, s. 412. 
„lilie”) (il. 1) trafiły do ich wspólnej publikacji, jednoaktówki przygotowanej ku czci Adama Mickiewicza ${ }^{34}$ z okazji odsłonięcia pomnika wieszcza na krakowskim Rynku.

Pierwsze wydanie poezji Rydla, które ukazało się jeszcze w 1898 roku (ale z datą wydania 1899) ${ }^{35}$, zostało opatrzone motywami różnych roślin, wśród których znalazły się omawiane białe lilie ${ }^{36}$. Autor wierszy uważał, że Wyspiański:

był pełen zawsze świeżych i szerokich pomysłów, skłonniejszy raczej do pewnej ekscentryczności niż do szablonów i rutyny, a nade wszystko zamiłowany w naturze, umie zawsze łączyć schematyczność, stanowiącą istotę sztuki dekoracyjnej - ze szczerym odczuciem i wiernym odtworzeniem motywów czerpanych wprost z przyrody ${ }^{37}$.

Tworząc szatę graficzną tomiku, Wyspiański nie kierował się chęcią dosłownego zilustrowania wierszy, jakkolwiek niektóre z nich opatrzył motywami znajdującymi odwołanie do roślin wzmiankowanych w utworach. Zabieg powtarzania tej samej ryciny przy różnych w treści wierszach nie wydaje się przypadkowy. Raczej świadczy o próbie oddania przez Wyspiańskiego nastroju zbieżnego z tekstem i ,znalezienia dla niego wizualizacji za pomocą wybranych motywów kwiatowych"38. Wydany tomik został przyjęty życzliwie - doceniony zarówno od strony literackiej, jak i oprawy graficznej. Krakowski „Czas” donosił:

należy się wzmianka ornamentacyjnym rysunkom p. Stanisława Wyspiańskiego (...). Jest tu moc kwiatów. Każdy prawie wierszyk ma osobne dla siebie kwiatki, które poniekąd odgrywają taką rolę, jaką w czasach kwitnienia romantyzmu odgrywały motta z ulubionych poetów ${ }^{39}$.

Wyspiański umieścił w tomiku parokrotnie winiety z białymi liliami. Ponad wierszem Chopin: Preludyum N.15 przedstawił roślinę z ulistnionym pędem i kielichami kwiatowymi w różnym ułożeniu i odmiennym stadium rozkwitu, uosabiającym przemijanie: górny kielich ledwo rozwinięty, następne trzy w pełnym rozkwicie oraz umieszczony najniżej szczątek kielicha, z zachowanymi jedynie na szypułce - słupkiem i pręcikami (por. il. 1). Motyw lilii został wpisany w prostokątne pole, ujęte konturową ramką ${ }^{40}$. Ten sam motyw, ale w dużym pomniejszeniu i pozbawiony ramki, został trzykrotnie powtórzony w układzie szeregowym i stworzył kolejną winietę (il. 2), która zdobi

${ }^{34}$ Epilog uroczystego przedstawienia w teatrze krakowskim w dniu 27-ego czerwca 1898 na cześć Adama Mickiewicza przez Lucjana Rydla i Stanisława Wyspiańskiego, Kraków 1898; il. „lilie” na s. 7.

${ }^{35}$ L. Rydel, Poezye I. Z rysunkami Stanisława Wyspiańskiego, Warszawa, Kraków 1899. Wyspiański, w liście do przyjaciela z 13 października 1898 roku, a więc zanim objął kierownictwo artystyczne „Życia”, słysząc, że „tom już jest zbroszurowany i gotowy”, pisze do przyjaciela: „śmiem Cię prosić o exemplarz". S. Wyspiański, Listy zebrane, t. 2, cz. 1..., s. 498.

${ }^{36}$ Do wykonania klisz posłużyły rysunki lilii, które potem trafiły do zbiorów Feliksa Jasieńskiego. Stanisław Wyspiański: dzieła malarskie..., s. 116, poz. 283.

${ }^{37}$ L. Rydel, Ze sztuki [Wyjątki] [w:] Wyspiański w oczach wspótczesnych ..., t. 1, s. 368.

38 J. Bajda, Poeci - to są słów malarze... Typy relacji między słowem a obrazem w ksiązkach poetyckich okresu Młodej Polski, „Acta Universitatis Wratislaviensis” 2010, nr 3245, s. 317.

${ }^{39} \mathrm{Z}$ recenzji Józefa Tretiaka, historyka literatury i krytyka literackiego, prof. UJ, J. Tretiak, Z najnowszej poezyi (Dokończenie), „Czas” 27.01.1899, nr 22, s. 1.

${ }^{40}$ L. Rydel, Poezye I. z rysunkami..., s. 52. W roku 1901 ukazało się drugie wydanie. 


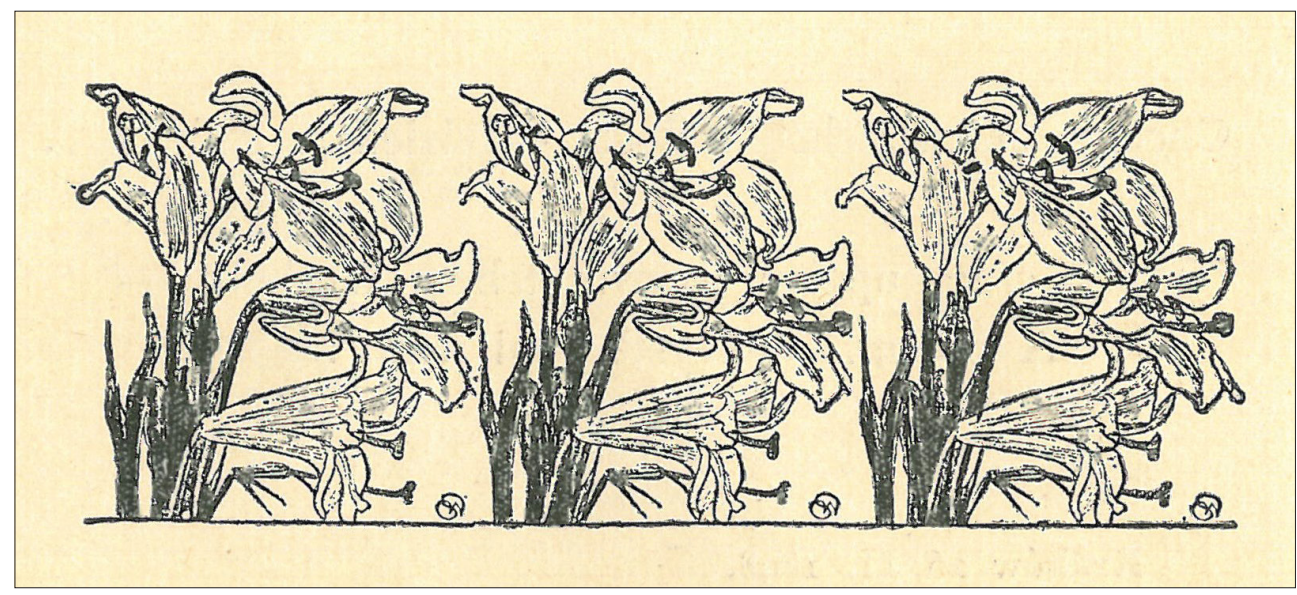

II. 2. Stanisław Wyspiański, winieta „Lilie” [w:] L. Rydel, Poezye I. Z rysunkami Stanisława Wyspiańskiego, Gebethner i Wolff, G. Gebethner i Spółka, Warszawa, Kraków 1899, s. 26. Fot. Biblioteka Jagiellońska

wiersze: W Maju, Przekleństwo oraz Wieczerza Pańska ${ }^{41}$. W 1902 roku owa winieta ${ }^{42}$ znów trafiła do tomiku wierszy, tym razem Marii Konopnickiej ${ }^{43}$. Alfred Nowaczyński $^{44}$ pisał, że Wyspiański „rysował kwiaty godzinami z pedanterią japońską”. Istotnie, była to pedanteria japońska, lecz połączona z własną inwencją. Elżbieta Skierkowska, komentując motywy w tomiku poezji Rydla, zauważyła, że jego ryciny „budzą reminiscencje lilii japońskiego artysty Hokusai”45. I dodaje: „Mimo to kompozycje kwiatów Wyspiańskiego są oryginalne i stanowią o jego odrębnym i samoistnym stylu" ${ }^{\prime 4}$. Tworząc swój styl, Wyspiański miał okazję skonfrontować własne pomysły z dziełami europejskich artystów podczas studiów w Paryżu w latach 1891-1894. Zapewne wtedy nadarzyła się także sposobność poznania francuskojęzycznych publikacji na temat Johna Ruskina i Williama Morrisa, oraz tłumaczenia ich dzieł ${ }^{47}$. Grafika angielska, jak pisze Karol Estreicher, o wiele silniej zaważyła na rysunkach Wyspiańskiego m.in. do „Zielnika” niż sztuka francuska ${ }^{48}$.

W 1894 roku wydarzeniem artystycznym ówczesnego Paryża stała się wystawa prac Eugène’a Grasseta (1844-1917), Szwajcara osiadłego we Francji, tworzącego w stylu

${ }^{41}$ Ibidem s. 3, 26, 78.

${ }^{42}$ Zamieszczona także w egzemplarzu „Życia”, 1.11.1899, nr 19/20.

${ }^{43}$ M. Konopnicka, Wybór pism, Jubileuszowe wydanie ludowe ze słowem, wstępem L. Rydla, z rysunkami S. Wyspiańskiego i ozdobą tytułową W. Wodzinowskiego, Kraków 1902, s. 138.

${ }^{44}$ A. Nowaczyński, op. cit.

${ }^{45}$ Katsushika Hokusai (1760-1849) jeden z najwybitniejszych artystów japońskich, twórca barwnych drzeworytów; jest autorem m.in. Lilii (ok. 1830 r.). Vide Katsushika Hokusai. The complete works. Lilies, https://www.katsushikahokusai.org/Lilies.html [dostęp: 29.01.2018].

${ }^{46}$ E. Skierkowska, Wyspiański artysta książki, red. A. Birkenmajer, wyd. 2, Wrocław 1970, ryc. 58, s. 125.

47 A. Szczerski, op. cit., s. 70.

${ }^{48}$ K. Estreicher, Wyspiański-Konrad [w:] Stanisław Wyspiański 1907-1957, Kraków 1958, s. 12. 
Art Nouveau, który realizował program i teorie prerafaelitów ${ }^{49}$. Francuska recepcja prerafaelitów z lat ok. 1869-1895 ukształtowała rozpowszechnione w Europie Środkowej postrzeganie dzieł brytyjskich artystów jako części ogólnoeuropejskiego symbolizmu ${ }^{50}$. Wyspiański prawdopodobnie obejrzał wystawę Grasseta ${ }^{51}$. Po powrocie do Krakowa nadal z uwagą śledził jego dokonania ${ }^{52}$. Tworząc projekty polichromii do kościoła Franciszkanów, niejako rywalizując z nim, przeciwstawił jego kwiatom ,poddanym nienaturalnemu secesyjnemu geometrycznemu rygorowi - własne rośliny, komponowane lekko, naturalnie i z wielką swobodą"53. Możliwość pokazania swoich umiejętności nadarzyła się ponownie, choć nie w tak dużej skali, gdy Wyspiański rozpoczął współpracę ze Stanisławem Przybyszewskim. W poezji młodopolskiej biała lilia miała wielorakie znaczenie. Mogła symbolizować zarówno dziewiczą niewinność, miłość platoniczną, jak i miłość zmysłową; przywoływała uczucia pasywne: znużenia, pesymizmu, duchowego samotnictwa, nieokreślonych tęsknot oraz przez barwę, delikatność i kruchość - nietrwałości życia, poczucia przemijania; towarzyszyła obrazom snu, ukojenia, spokoju, ale także wraz z innymi białymi kwiatami - przedstawieniom śmierci ${ }^{54}$. Toteż znakomicie dopełniała wydawaną poezję i wpisywała się w charakter czasopisma „Życie”, pod redakcją Stanisława Przybyszewskiego i z oprawą plastyczną Wyspiańskiego. Winieta z lilią w ramce zdobiąca wcześniej tomiki Rydla została pokazana ponownie w prospekcie reklamowym „Życia" ${ }^{55}$ oraz na karcie tytułowej, pierwszego numeru rozpoczynającego rok $1899^{56}$. Potem pojawiała się jeszcze kilkakrotnie ${ }^{57}$. Zenon Przesmycki-Miriam, który z Paryża śledził poczynania twórców pisma, w liście do Przybyszewskiego pisał, że

49 E. Skierkowska, op. cit., s. 59.

${ }^{50}$ A. Szczerski, op. cit., s. 71.

${ }^{51}$ Wiadomo, że nabył katalog jego wystawy Catalogue de la deuxième exposition du salon des cent resérvée à un ensemble d'oeuvres d'Eugène Grasset i opatrzywszy podpisem „Stanisław Wyspiański Paris 1894 rp.”, przesłał Rydlowi. S. Wyspiański, Listy zebrane, t. 2, cz. 2..., s. 185. Justyna Bajda przypuszcza, że wówczas poznał także jego wcześniejszą publikację Ornements typographique, Paris 1880. J. Bajda, op. cit., s. 314.

${ }^{52}$ W liście do Rydla (20 maja 1897), pisał: ,już dzisiaj mam posażne materiały, i daleko lepiej przypuszczam niż Grasset potrafiłbym dać „stylowe rośliny”, w całym olbrzymim tomie, chociaż nie znam publikacji Grasseta, ale wiem, że istnieje i że świeżo wyszła - zaledwo pod jego kierunkiem, podczas gdybym ja sam wszystko zrobił”. S. Wyspiański, Listy zebrane, t. 2, cz. 1..., s. 467. W liście mowa o albumie prac: La plante et ses applications ornementales, Paris [1896], powstałych pod kierunkiem Grasseta i wydanym z jego wstępem -egzemplarz dostępny w internecie m.in. w Bibliothèque de l'Insitut National d'Histoire de l'art w Paryżu, https://bibliotheque-numerique.inha.fr/collection/ item/19965-la-plante-et-ses-applications-ornementales [dostęp: 24.04.2018].

${ }_{53}$ W. Bałus, Sztuka sakralna Krakowa w wieku XIX, cz. 2: Matejko i Wyspiański, Kraków 2007, s. 100 .

${ }^{54}$ I. Sikora, Symbolika kwiatów w poezji Młodej Polski, „Rozprawy i Studia”, Uniwersytet Szczeciński, t. 18 (XCII), Szczecin 1987, s. 39, 55-57.

${ }^{55}$ S. Wyspiański, Dzieła zebrane, t. 16, vol. II: Kalendarz życia i twórczości 1 marca 1890 - ostatnie dni marca 1898 Stanisława Wyspiańskiego, oprac. M. Stokowa, Kraków 1982, il. 24, s. 452.

${ }^{56}$, „Życie” 10.01.1899, nr 1.

${ }^{57}$ W nr: 4, 13/14, 19/20. W numerze 19/20 z 1.11.1899 umieszczono obie wersje lilii - tę wpisaną $\mathrm{w}$ ramkę i tę w winiecie złożonej z trzech pomniejszonych motywów. 
„Życie” pod względem typograficznym „stoi na wyżynie najwybredniejszego smaku artystycznego w Europie" 58 .

Omawiając stylizacje kwiatowe Wyspiańskiego występujące w plastyce, trudno nie wspomnieć o temacie lilii, który pojawił się także w kontekście niezrealizowanego przez niego projektu libretta do opery. Wyspiański, podobnie jak francuscy symboliści, łączył różne dziedziny sztuki. Muzykę „nie tylko czuł głęboko, nie tylko robiła na nim nadzwyczajne wrażenie, ale w tej sferze znajdował źródło wielkiego natchnienia" ${ }^{99}$. Wyspiański, kochając teatr, marzył o polskiej operze. „Ja chcę stworzyć operę polską, którą Moniuszko zaledwo rozpoczął. Ja chcę ją prowadzić w obmyślanej przeze mnie całości muzycznej i w szczegółach" ${ }^{\circ 0}$ - tak pisał Wyspiański do Felicjana Szopskiego w lipcu 1904 roku. Wcześniej Szopski przedstawił mu projekt napisania opery na podstawie ballady Lilie Mickiewicza, jednakże współpraca ich obu nie doszła do skutku. Wyspiański rzecz skwitował następująco: „Lilie zostaną u mnie w biurku”61.

Rok 1904 był dla Wyspiańskiego okresem wytężonej pracy i zaowocował licznymi realizacjami zarówno w dziedzinie literatury, jak i plastyki (w tym kostiumologii, meblarstwa i rzemiosła artystycznego). Do niezrealizowanych projektów z tego roku należy dekoracja sali krakowskiego Archiwum Aktów Dawnych, gdzie Wyspiański planował umieszczenie na sklepieniu fryzu z białych lilii ${ }^{62}$. W swoim Raptularzu z 1904 roku 22 września odnotował: „Rysuję »lilie« dla Archiwum”, a 28 września dodał: „Kalkuję »lilie« do Archiwum"63. We wrześniu Wyspiański zaprojektował także kasetę z dekoracją kwiatową w płycinach, do której posłużył mu gotowy motyw. Graficzne lilie zdobiące wiersze Rydla tym razem zostały przetworzone w wersję barwną. Projekt kasety ${ }^{64}$ (il. 3), sygnowany (wiązany monogram SW oraz data 1904) obejmuje szczegółowy rysunek (ołówkiem i kredkami) licowej ścianki kasety z dwoma motywami lilii (w układzie antytetycznym), jednej z nóżek oraz uchwytu do wieka w postaci zamontowanych ludowych krakowskich męskich spinek. Obok rysunku lica kasety występuje rysunek kluczyka (z opisem uchwytu), powyżej autorski opis wersalikami: „kaseta/malowana: farbami emaliowemi/lilie: biały kwiat/granatowe tło lub czarne/drzewo zapuszczone czarno/spinki chłopskie/okucie - blaszka mosiężna”, a przy dolnym brzegu rysunku

${ }^{58}$ S. Przybyszewski, Wspomnienie [w:] Wyspiański w oczach wspótczesnych..., t. 1, s. 390.

${ }^{59}$ Felicjan Szopski (1865-1939) kompozytor i krytyk muzyczny. F. Szopski, Wyspiański a opera polska [w:] S. Wyspiański, Listy zebrane, t. 4..., s. 292.

${ }^{60}$ S. Wyspiański, Listy zebrane, t. 4..., s. 293.

${ }^{61}$ Ibidem, s. 619.

${ }^{62}$ S. Wyspiański, List do Stanisława Krzyżanowskiego, dyrektora archiwum, 13 X 1904 roku [w:] idem, Listy zebrane, t. 4..., s. 297.

${ }_{63}$ Idem, Raptularz z roku 1904 roku [w:] idem, Listy zebrane, t. 4..., s. 375, 376.

${ }^{64}$ W Raptularzu z 1904 roku, pod datą 21 IX widnieje wpis : „Rysuję »kasetę«”, ibidem, s. 375. Rysunek, papier, ołówek, kredka, wys. 28,5 cm, szer. 39,5 cm (wymiary w świetle passe-partout) nr inw. 17189; zakup od Pawła Midowicza z Krakowa w 2000 roku. Bardzo często wzory dekoracji przygotowane przez Wyspiańskiego dla rzemieślników zmieniały z czasem swoje przeznaczenie, stając się artefaktami pożądanymi przez kolekcjonerów. Wyspiański, w liście z 6 III 1905 roku do Antoniny Sikorskiej właścicielki warsztatu kilimkarskiego prosi o odesłanie wzoru na kilim do domu lekarskiego „gdyż mam nabywcę, który chce wzór ten zakupić do swoich zbiorów”. S. Wyspiański, Listy zebrane, t. 4 ..., s. 304. 
niebieską kredką: „wyrzeźbić w plastelinie cały front ${ }^{65}$. To, co uderza w projekcie, to zastosowanie nie tyle motywów folkloryzujących, ile pomysł wmontowania autentycznych, jak mawiał Tadeusz Seweryn, „klejnotów krakowskich”. Do krakowskiej chłopskiej biżuterii należały męskie spinki do spinania koszul pod szyją (w ten sam sposób jak dzisiejsze spinki do mankietów), wykonywane ze srebra lub bakfonu z czerwonym koralem (lub jego imitacją) ${ }^{66}$. Nie był to jedyny taki pomysł Wyspiańskiego, aby wprowadzić motywy ludowych ozdób do repertuaru zdobień projektowanego przedmiotu. We wspomnianych już zbiorach dr Bernarda Steinberga znajdował się rysunek kielicha, w którym w miejscu nodusa Wyspiański wkomponował motyw krakowskiego pierścienia z koralem ${ }^{67}$. Dla Wyspiańskiego sztuka ludowa stanowiła bogaty zasób motywów, które w sposób twórczy przetwarzał, projektując kostiumy teatralne i sprzęty. Nie wykluczone, że inspiracją dla artysty była sama funkcja zamykanej na klucz wyprawowej skrzyni, dekorowanej barwną malaturą. W okresie jego zainteresowań podkrakowskim folklorem wianne skrzynie różnej wielkości znajdowały się niemal w każdym chłopskim domu. Należały do szanowanych mebli - jak mawiano we wsi Faściszowa (pow. Tarnów): „Skrzynia u chłopa była jak Arka (przymierza) u Żydów”68.

Rysunek kasety powstał w okresie wzmożonych prac Wyspiańskiego i przygotowań do ekspozycji „Świetlicy” na Wystawę Jubileuszową Towarzystwa Artystów Polskich „Sztuka” organizowaną w Pałacu Sztuki oraz wystroju wnętrz Domu Towarzystwa Lekarskiego $^{69}$. Charakterystyczny kształt kluczyka przewidzianego do kasety (por. il. 3), z uchwytem o brzegu wycinanym w precyzyjne półkola (opisany przy rysunku przez Wyspiańskiego: „okrąg rzeźbiony półokrągło”), przypomina najwyraźniej rysowane wówczas projekty blaszek do oznaczania dzieł sztuki, które miały być zaprezentowane w Pałacu Sztuki ${ }^{70}$.

Kaseta została wykonana ${ }^{71}$ i ozdobiona z pewnymi odstępstwami od projektu. W bejcowanym na ciemno (kolor hebanu) korpusie kasety pojawiły się błękitne płyciny zamiast

${ }^{65}$ Tej informacji odpowiada wpis w Raptularzu na rok 1904, pod datą 22 IX: „rzeźbię lilie”. S. Wyspiański, Listy zebrane, t. 4..., s. 375.

${ }^{66}$ E. Piskorz-Branekova, Polskie stroje ludowe, Warszawa 2003, s. 117; takie spinki miewały wysokość 2,3 cm i śr. podst. ok. 1,7 cm. E. Rossal, Spinka do koszuli męskiej, krakowskiej, vide: muzea. malopolska.pl/obiekty/-/a/content/1131755/26822/pop_up?_101static... [dostęp: 19.03.2018].

67 T. Seweryn, op. cit., s. 26.

${ }^{68}$ R. Reinfuss, Ludowe skrzynie malowane, Warszawa 1954, s. 7.

${ }^{69}$ Zachowały się rysunki: szafy i stołu prezydialnego, mebli projektowanych do wystroju wnętrz towarzystwa, L. Bularz-Różycka, Nieznane rysunki Stanisława Wyspiańskiego ze zbiorów Muzeum Uniwersytetu Jagiellońskiego, Kraków, 2007, s. nlb, il. 27, 36.

70 Wyspiański. Katalog wystawy..., s. 372, 398, il. VII.7.

${ }^{71}$ Kaseta: wys. 18 cm, szer. 26,5 cm, gł. 13,7 cm, nr inw. 6287; drewno bejcowane (korpus kasety w kolorze hebanu, wnętrze jasne), prostopadłościenna, z wiekiem na zawiasach, pierwotnie zamykana na klucz; ścianki korpusu z prostokątnymi płycinami, w których malowane motywy białych lilii; sygnatura ryta w malaturze bocznej ścianki [monogram wiązany SW oraz data 1904 (il. V), w charakterze autografów znanych z dzieł malarskich Wyspiańskiego z tego okresu]. Kaseta intensywnie używana [z wypaczonym wiekiem nadłamanym przy zawiasie; miejscami z ubytkami drewna i wytarciami malatury]. Nabyta w krakowskiej „Desie”, Rynek Gł. 17, w 1959 roku; fundusz na zakup pochodził z uniwersyteckich kredytów niewykorzystanych przez Zakład Fizyki UJ, Archiwum Muzeum Uniwersytetu Jagiellońskiego, Protokół konieczności z 30 XII 1959 r. podpisany przez prof. Adama Bochnaka. 


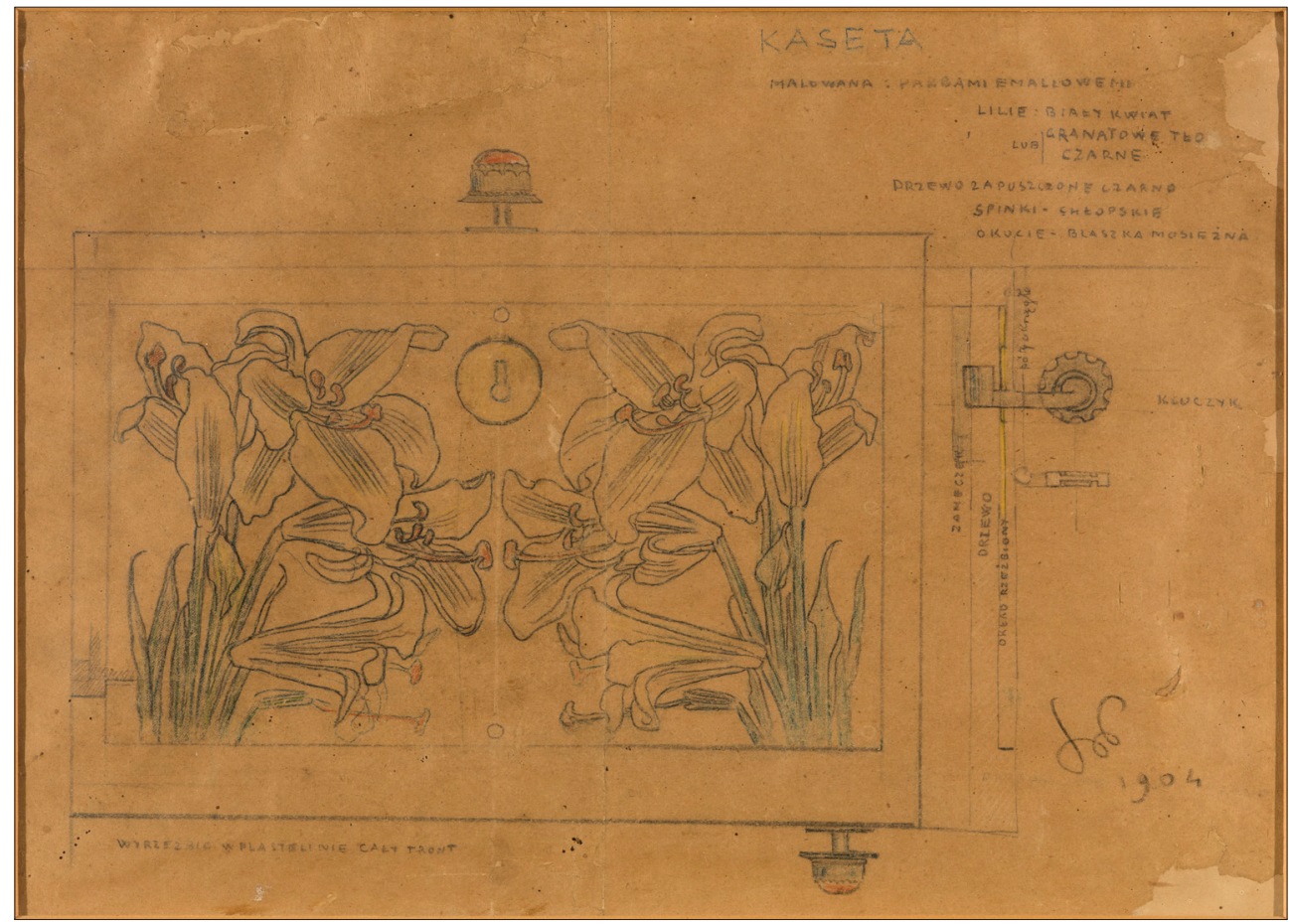

Il. 3. Stanisław Wyspiański, projekt kasety. Fot. G. Zygier

projektowanych granatowych lub czarnych (por. il. I-IV), na ich tle (w ściance licowej i tylnej) występują dwa motywy białych lilii w układzie antytetycznym, w bocznych motywy pojedyncze, a wieko pozostało niezdobione. W malaturze wypełniającej płyciny użyto: biel, błękit, zieleń, oranż, brąz, czerń; widoczny jest sposób nakładania warstw farby; miejscami na obrzeżach pól wypełnionych kolorem są widoczne ciemne linie wstępnego zarysu kompozycji. Nie zostały zamontowane krakowskie spinki ani szyldzik zamka. Ponieważ nie zachował się kluczyk, nie wiadomo, czy był wykonany według projektu.

W okresie malowania kasety Wyspiański jednocześnie projektował wnętrza oraz oryginalne formy mebli, będące pierwszymi w Polsce realizacjami w stylu Art Déco. W projektach mebli Wyspiański zrezygnował ze zdobniczych walorów secesyjnej giętkiej linii oraz bujności i żywotności roślinnej ornamentyki na korzyść prostych linii, bryłowatych kształtów i symetrycznej, skromnej dekoracji podporządkowanej konstrukcji i tworzywu ${ }^{72}$. Zdobiąc kasetę, należącą jako wyrób do stolarskiej galanterii, uzyskał końcowy efekt estetyczny podobny w realizacji do efektu wnętrza sali posiedzeń Domu Towarzystwa Lekarskiego, gdzie z barwnym opracowaniem ścian zdobionych motywami kwiatowymi, kontrastowały bejcowane na ciemno obramienia drzwi i ciemne meb$\mathrm{le}^{73}$. Natomiast białe lilie, powtórzone w ogólnym kształcie za winietą z 1898 roku, nie przeszły jeszcze takiego zabiegu geometryzacji, jaką Wyspiański zastosował, projektując

\footnotetext{
72 A. Sieradzka, op. cit., s. 133.

${ }^{73}$ Ibidem, s. 135.
} 
fryz z geranii do tej Sali. Zostały jednak już uproszczone i pozbawione finezyjnie opracowanych szczegółów występujących w pierwowzorze.

O stosowanych technikach malarskich Wyspiański nieraz wspominał w korespondencji z rodziną i przyjaciółmi - 11 grudnia 1890 roku zanotował: ,jutro kupuję olejne farby na rozkaz mistrza Matejki, pojutrze zaczynam malować olejowo"74. Dziesięć dni później dodał: „Malowałem modela całe rano, ale jeszcze nie Van Eycka wielkim wynalazkiem (...), ale »wodelkami «"75. Rok później stwierdził: „,z farbami olejnemi w ciągłej jestem niezgodzie, zdaje się, że mi w ogóle farby olejne szkodzą" "76. Ze względu na zdrowie i zapewne powodowany także ówczesną modą na rysowanie pastelami już w Paryżu podjął tę technikę - zapisał: „Jestem zajęty całemi dniami (...) pastelowaniem portraitów przeróżnych ludzi" 77 . Po powrocie ze studiów paryskich w 1894 roku, okazjonalnie sięgał do zarzuconej techniki (,,witraż mój jest malowany częściowo olejno, w znacznej zaś części farbami emaliowemi, które w efekcie są o wiele silniejsze i żywsze niż farby olejne"78). W styczniu 1904 roku technikę Wyspiańskiego zobligowały aktualne potrzeby. Replikę projektu witraża Bóg Ojciec do zachodniego okna nawy kościoła Franciszkanów malował temperą emulsyjną ${ }^{79}$, a we wrześniu kasetę, według opisu w projekcie, „farbami emaliowemi”.

Wyspiański malował kasetę w kolejnym ze swoich krakowskich mieszkań, zajmowanym w latach 1901-1906. Pracownia, w której tworzył, mieściła się, zdaniem Feliksa Jasieńskiego (Mangghi): „we wstrętnej kamienicy (ostatnia na prawo, narożna, przy torze kolejowym) przy wstrętnej ulicy - Krowoderskiej, na drugim piętrze (...)”, w pokoju pomalowanym „bardzo przykrym (...) - kolorem zjadliwie błękitnym" ${ }^{\circ 0}$. Zupełnie inne wrażenia odniósł odwiedzający Wyspiańskich Józef Filipowski:

Mieszkanie Wyspiańskiego było niezwykle oryginalne (...). Wszystkie sprzęty w pokoju Wyspiańskiego wykonane były wedle jego rysunkowych projektów i wskazówek (...). Artystyczna

${ }^{74}$ S. Wyspiański, Listy zebrane, t. 3: Listy Stanistawa Wyspiańskiego do Karola Maszkowskiego, teksty listów oprac. i komentarz M. Rydlowa, z wykorzystaniem materiałów L. Płoszewskiego, J. Dürra-Durskiego, Kraków, 1997, s. 8.

${ }^{75}$ Tzn. akwarelą. Vide ibidem, s. 28.

${ }^{76}$ S. Wyspiański, List do Janiny i Kazimierza Stankiewiczów, Paryż, 8 X 1891 roku [w:] idem, Listy zebrane, t. 4..., s. 46. Domieszka bieli ołowianej (bleiweißu) niezbędna przy malowaniu olejnym zatruwała jego organizm, toteż za poradą paryskiego lekarza porzucił malowanie tą techniką. W. Ekielski, Wspomnienia o Wyspiańskim [w:] Wyspiański w oczach współczesnych..., t. 1, s. 363.

77 S. Wyspiański, List do H. Opieńskiego, Paryż 25 VII 1893 roku [w:] idem, Listy zebrane, t. 1: Listy Stanisława Wyspiańskiego do Józefa Mehoffera, Henryka Opieńskiego i Tadeusza Stryjeńskiego, cz. 1: Listy, teksty listów opracowała M. Rydlowa, Kraków 1994, s. 171.

${ }^{78}$ S. Wyspiański, List do Władysława Łozińskiego w zwiąku z kartonem do zamówionego witraża dla Katedry lwowskiej, Paryż, 10 VIII 1894 [w:] idem, Listy zebrane, t. 4..., s. 103.

${ }^{79}$ Według Adama Chmiela: „1/2 olejnymi farbami”. A. Chmiel, [Zapiski z rozmów z Wyspiańskim] [w:] Wyspiański w oczach współczesnych ..., t. 2, s. 130. Według obecnych badań: temperą emulsyjną. Wyspiański. Katalog wystawy..., s. 158, kat. III 16.

${ }^{80}$ F. Jasieński [Ze wspomnień] [w:] Wyspiański w oczach współczesnych ..., t. 2, s. 399. Mieszkanie Wyspiańskich wg Adama Chmiela znajdowało się ,na Krowodrzy nr 157, na II piętrze w kamienicy p. Stillera". A. Chmiel, Nieco ze wspomnień o Stanistawie Wyspiańskim (1869-1907), Wyspiański w oczach wspótczesnych..., t. 2, s. 150. 
swoboda w układzie sprzętów i przedmiotów sprawiała, że przebywanie w mieszkaniu Wyspiańskiego należało do prawdziwych przyjemności ${ }^{81}$.

Goście odwiedzający Wyspiańskiego obserwowali także jego stosunek do żony Teodory Teofili z Pytków (1868-1957). Wyspiański, przy swojej ogromnej wrażliwości, musiał nieraz znosić lekceważenie małżonki, nietolerowanej w mieszczańskim światku (jak pisał: „moja żona nie jest z »miastowych « z tak zwanej inteligencji”) ${ }^{82}$. Toteż w kontaktach towarzyskich zawsze podkreślał swoje uczucia do niej i szacunek. Gdy któregoś dnia Tytus Czyżewski odwiedził Wyspiańskiego przy ul. Krowoderskiej, ten „nagłym i nieprzewidzianym ruchem zwrócił się do stołu, na którym stał wazon ślicznej, biało kwitnącej azalii. - A to, widzi pan, dostałem od mojej żony na imieniny" "83. Według opinii Stanisława Estreichera, przyjaciela artysty: „(...) Wyspiański lubił dziewczyny proste, proletariackie czy chłopskie (...), panien z domów inteligenckich nie lubił, nie interesowały go" "84. Pisząc o urodzie kobiet ze swojego środowiska, Wyspiański porównał je z kwiatami: „są jakby kwiatami pośród ziół silnie pachnących, kwiaty bez woni, ale ładne kolorem i kształtem" "85. Wyspiański kochał swoją żonę ${ }^{86}$. W opinii Józefa Kotarbińskego: „Był istotnie przywiązanym, nawet ślepo uległym mężem (...). Uczucia rodzinne należały dlań do świętości, których tykać nie było wolno »bo trza, żeby święte były«"87. Teodora była dla niego żoną i matką jego dzieci, a także osobą, którą wielokrotnie portretował i o której napisał „w dniach smutku i osamotnienia najpiękniejsze wiersze"88. Sporo szczegółów z życia codziennego małżonków zawierają wspomnienia Antoniego Waśkowskiego, kuzyna Wyspiańskiego. O Wyspiańskim i jego relacjach z żoną pisał:

Cieszyła go radość żony z drobiazgów, które on jej ofiarował. Mam w oczach coraz to nowe gorsety haftowane czy wyszywane według rysunku Wyspiańskiego - szkatułkę drewniana z prześlicznym motywem lilii na wieku i na bokach pudełka [podkr. - A.P.], a dalej - przepiękne wzory haftów na kołnierzach i manszetach koszul. Artysta sam wybierał materie na spódnice dla żony, materie te musiały mieć kwiaty charakterystyczne dla wsiowych spódnic ${ }^{89}$.

81 Józef Filipowski (1870-1941) zarządca Drukarni Uniwersytetu Jagiellońskiego, w której drukowano utwory Wyspiańskiego. J. Filipowski, Wspomnienia o Stanisławie Wyspiańskim [w:] Wyspiański w oczach wspótczesnych..., t. 2, s. 187-188.

82 S. Wyspiański, List do Stanisława Lacka, 7 V 1905 roku [w:] idem, Listy zebrane, t. 4..., s. 355.

83 T. Czyżewski, Mistrz z ulicy Krowoderskiej [w:] Wyspiański w oczach współczesnych..., t. 2, s. 421.

${ }^{84}$ Opinię Stanisława Estreichera zanotował jego syn Karol Estreicher. K. Estreicher jr., Dziennik wypadków, t. 2: 1946-1960, Kraków 2002, s. 495-496.

${ }^{85}$ S. Wyspiański, List do Józefa Mehoffera, Kraków, 14-17 I 1893 roku [w:] idem, Listy zebrane, t. 1 , cz. $1 \ldots$, s. 106.

${ }^{86}$ K. Estreicher jr., Dziennik wypadków..., t. 2, s. 496.

${ }^{87}$ J. Kotarbiński [z książki Pogrobowiec romantyzmu. Rzecz o Stanisławie Wyspiańskim] (Wyjątki) [w:] Wyspiański w oczach wspótczesnych..., t. 2, s. 277-278.

${ }^{88}$ K. Zbijewska, Orzet w kurniku. Z życia Stanisława Wyspiańskiego, Warszawa 1980, s. 138.

89 A. Waśkowski, Znajomi z tamtych czasów [literaci, malarze, aktorzy] (1892-1939), wyd. 2 przejrz. i uzup., Kraków 1960, s. 51. Bogaty krakowski strój małżonki uwiecznił Wyspiański m.in. w jednym z jej portretów (1902 rok) [obecnie w zbiorach Muzeum Narodowego w Warszawie]. Wyspiańska występuje tam w haftowanej koszuli, gorsecie i katanie. Katany z rękawami, zdobione 
Pamięć bywa zawodna. Waśkowski pomylił się, opisując kasetę („,szkatułkę”, jak ją określał) z malowanymi liliami. Wieko nie było zdobione. Kolejna pomyłka wkradła się tym razem do publikacji Moniki Śliwińskiej: „Dla Teosi Wyspiański zamówił drewnianą kasetkę na pieniądze. Maluje ją na biało (sic!) i zdobi niebieskimi liliami” (sic! ${ }^{90}$. Raptularz Wyspiańskiego z 1904 roku nie zachował się. Treść notatek w nim zawartych jest znana z odpisów Leona Płoszewskiego ${ }^{91}$. O ile notatka z 28 września została prawidłowo odczytana z oryginału: „Sydor oddaje kasetki zapuszczone czarno [podkr. - A.P.], maluję tło błękitne", stolarz przyniósł kilka kaset (być może do wyboru). Następnego dnia Wyspiański odnotował: „Rano maluję lilie na kasecie”92. Na tej, którą przeznaczył jako prezent dla żony.

\section{Bibliografia}

\section{Archiwalia}

Archiwum Muzeum Uniwersytetu Jagiellońskiego, Protokół konieczności zakupu dzieł sztuki z 30 XII 1959 r. podpisany przez prof. Adama Bochnaka, maszynopis.

\section{Czasopisma}

„Czas”, 3.03.1905, nr 51, wyd. wieczorne.

„Czas”, 2.03.1918, nr 101.

„Kalendarz Krakowski Józefa Czecha na rok 1905”.

„Krakowski Miesięcznik Artystyczny”, 1.07.1911, nr 6.

„Nowa Reforma”, 3.03.1905, nr 51.

„Nowa Reforma”, 14.05.1910, nr 217.

„Sztuka Stosowana” 1907, z. 10.

„Sztuka Stosowana” 1909, z. 13.

„Życie”, 10.01.1899, nr 1.

„Życie”, 15.02.1899, nr 4.

„Życie”, 25.07.1899, nr 13/14.

„Życie”, 1.11.1899, nr 19/20.

\section{Źródta}

Chmiel A., [Zapiski z rozmów z Wyspiańskim] [w:] Wyspiański w oczach współczesnych, zebrał, oprac. i komentarzem opatrzył L. Płoszewski, Kraków 1971, t. 2, s. 119-132.

analogicznie jak gorsety, były w okresie Młodej Polski najbardziej cenionym przez krakowianki rodzajem kaftanów, E. Piskorz-Branekova, op. cit.s. 120.

${ }_{90}$ M. Śliwińska, Wyspiański. Dopóki starczy życia, Warszawa 2017, s. 277.

${ }_{91}$ S. Wyspiański, Listy zebrane, t. 4..., s. 422.

${ }^{2}$ Por. przypis 9. 
Chmiel A., Nieco ze wspomnień o Stanisławie Wyspiańskim (1869-1907) [w:] Wyspiański w oczach współczesnych zebrał, oprac. i komentarzem opatrzył L. Płoszewski, Kraków 1971, t. 2, s. 143-152.

Czyżewski T., Mistrz z ulicy Krowoderskiej [w:] Wyspiański w oczach współczesnych, zebrał, oprac. i komentarzem opatrzył L. Płoszewski, Kraków 1971, t. 2, s. 419-421.

Ekielski W., Wspomnienia o Wyspiańskim [w:] Wyspiański w oczach współczesnych, zebrał oprac. i komentarzem opatrzył L. Płoszewski, Kraków 1971, t. 1, s. 352-364.

Estreicher K. jr., Dziennik wypadków, t. 2: 1946-1960, Kraków 2002.

Filipowski J., Wspomnienia o Stanisławie Wyspiańskim [w:] Wyspiański w oczach współczesnych, zebrał, oprac. i komentarzem opatrzył L. Płoszewski, Kraków 1971, t. 2, s. 184-192.

Jasieński F., [Ze wspomnień ] [w:] Wyspiański w oczach współczesnych, zebrał, oprac. i komentarz L. Płoszewski, Kraków 1971, t. 2, s. 399-402.

Kotarbiński J. [z książki Pogrobowiec romantyzmu. Rzecz o Stanisławie Wyspiańskim] [w:] Wyspiański w oczach współczesnych, zebrał, oprac. i komentarzem opatrzył L. Płoszewski, Kraków 1971, t. 2, s. 273-278.

Mączewski P. [Notatki z rozmów z Janina Stankiewiczowa] [w:] Wyspiański w oczach wspótczesnych, zebrał oprac. i komentarzem opatrzył L. Płoszewski, Kraków 1971, t. 1, s. 25-27.

Mrozicka z Waśkowskich F., Z życia Wyspiańskiego [w:] Wyspiański w oczach współczesnych, zebrał oprac. i komentarzem opatrzył L. Płoszewski, Kraków 1971, t. 1, s. 41-45.

Niesiołowski T., [Z tomu ,, Wspomnienia” [w:] Wyspiański w oczach współczesnych, zebrał, oprac. i komentarzem opatrzył L. Płoszewski, Kraków 1971, t. 2, s. 428-430.

Nowaczyński A., Wyspiander (Moje wspomnienia) [w:] Wyspiański w oczach współczesnych, zebrał, oprac. i komentarzem opatrzył L. Płoszewski, Kraków 1971, t. 1, s. 418-432.

Pismo Święte Starego i Nowego Testamentu, Biblia tysiaclecia, w przekładzie z języków oryginalnych opracował zespół biblistów polskich z inicjatywy Benedyktynów tynieckich, red. o. A. Jankowski OSB, ks. L. Stachowiak (ST), ks. K. Romaniuk (NT), wyd. 2 zmien., Poznań, Warszawa 1971.

Przybyszewski S., Wspomnienie [w:] Wyspiański w oczach współczesnych, zebrał, oprac. i komentarzem opatrzył L. Płoszewski, Kraków 1971, t. 1, s. 388-393.

Rydel L., Ze sztuki [Wyjątki] [w:] Wyspiański w oczach współczesnych, oprac. i komentarzem opatrzył L. Płoszewski, Kraków 1971, t. 1, s. 365-369.

Siedlecki M., Wspomnienia o Wyspiańskim i Reymoncie [w:] Wyspiański w oczach współczesnych, zebrał, oprac. i komentarzem opatrzył L. Płoszewski, Kraków 1971, t. 2, s. 193-200.

Tretiak J., Z najnowszej poezyi ( Dokończenie) , Czas”, 27.01.1899, nr 2.

Waśkowski A., Znajomi z tamtych czasów [literaci, malarze, aktorzy](1892-1939), wyd. 2 przejrz. i uzup., Kraków 1960.

Wysocki A., Z pamiętników ,Sprzed pót wieku” [w:] Wyspiański w oczach współczesnych, zebrał, oprac. i komentarzem opatrzył L. Płoszewski, Kraków 1971, t. 1, s. 411-417.

Wysocki Godziemba A., Ze wspomnień o Wyspiańskim [W skróceniu] [w:] Wyspiański w oczach współczesnych, zebrał, oprac. i komentarzem opatrzył L. Płoszewski, Kraków 1971, t. 1, s. 474-480.

Wyspiański S., Listy zebrane, t. 1: Listy Stanisława Wyspiańskiego do Józefa Mehoffera, Henryka Opieńskiego i Tadeusza Stryjeńskiego, cz. 1: Listy, teksty listów oprac. M. Rydlowa, Kraków 1994.

Wyspiański S., Listy zebrane, t. 2: Listy Stanisława Wyspiańskiego do Lucjana Rydla, cz. 1: Listy i Notatnik z podróży, teksty listów oprac. L. Płoszewski, M. Rydlowa, Kraków 1979.

Wyspiański S., Listy zebrane, t. 2: Listy Stanisława Wyspiańskiego do Lucjana Rydla, cz. 2: Dodatek krytyczny, napisali L. Płoszewski, M. Rydlowa, Kraków 1979. 
Wyspiański S., Listy zebrane, t. 3: Listy Stanisława Wyspiańskiego do Karola Maszkowskiego, teksty listów oprac. i komentarz M. Rydlowa, z wykorzystaniem materiałów L. Płoszewskiego, J. Dürra-Durskiego, Kraków 1997.

Wyspiański S., Listy zebrane, t. 4: Listy różne do wielu adresatów, teksty listów oprac. i komentarz M. Rydlowa, z wykorzystaniem materiałów L. Płoszewskiego, Kraków 1998.

\section{Zbiory poezji}

Konopnicka M., Wybór pism, Jubileuszowe wydanie ludowe ze słowem wstępnem L. Rydla, z rysunkami S. Wyspiańskiego i ozdobą tytułową W. Wodzinowskiego, Kraków 1902.

Rydel L., Poezje I. Z rysunkami Stanisława Wyspiańskiego, Warszawa, Kraków 1899.

\section{Opracowania}

Bajda J., Poeci - to są słów malarze... Typy relacji między słowem a obrazem w książach poetyckich okresu Młodej Polski, „Acta Universitatis Wratislaviensis” 2010, nr 3245.

Bałus W., Sztuka sakralna Krakowa w wieku XIX, cz. 2: Matejko i Wyspiański, Kraków 2007.

Bularz-Różycka L., Nieznane rysunki Stanisława Wyspiańskiego ze zbiorów Muzeum Uniwersytetu Jagiellońskiego, Kraków 2007.

Estreicher K., Collegium Maius i zbiory Muzeum uniwersytetu Jagiellońskiego, Kraków 1967. Estreicher K., Muzeum Uniwersytetu Jagiellońskiego, Warszawa, Kraków 1980.

Estreicher K., Wyspiański - Konrad [w:] Stanisław Wyspiański 1907-1957, Kraków 1958.

Güttler J., Stanisław Wyspiański (1869-1907). Obrazy i rysunki ze zbiorów lwowskich. Wystawa urządzona ku uczczeniu 25-tej rocznicy zgonu artysty, listopad-grudzień 1932, Lwów 1932.

Kawałko M.J., Historie ziołowe, Lublin 1986.

Mowszowicz J., Przewodnik do oznaczania krajowych roślin zielarskich, wyd. 2, Warszawa 1985.

Piękno darowane. Dzieła ofiarowane Uniwersytetowi Jagiellońskiemu w zbiorach Collegium Maius. Katalog wystawy zorganizowanej w Collegium Maius Uniwersytetu Jagiellońskiego $w$ dniach 7 maja - 6 sierpnia 2014 roku z okazji jubileuszu 650-lecia uczelni, red. J. Pollesch, M. Zdanek, Kraków 2014.

Piskorz-Branekova E., Polskie stroje ludowe, Warszawa 2003.

Reinfuss R., Ludowe skrzynie malowane, Warszawa 1954.

Rossal E., Spinka do koszuli męskiej, krakowskiej, https://muzea.malopolska.pl/obiekty/-/a/content/1131755/26822/pop_up?_101static_viewMode=print [dostęp: 19.03.2018].

Seweryn T., Indywidualność plastyczna Wyspiańskiego, „Rzeczy Piękne” 1932, R. 11, nr 1-12, s. $12-29$.

Sieradzka A., Stanisław Wyspiański jako prekursor stylu Art Déco w polskim rzemiośle artystycznym [w:] Rzemiosto artystyczne. Materiały Sesji Oddziału Warszawskiego Stowarzyszenia Historyków Sztuki, red. R. Bobrow, Warszawa 1996, s. 131-143.

Sikora I., Symbolika kwiatów w poezji Młodej Polski, „Rozprawy i Studia”, Uniwersytet Szczeciński, t. 18 (XCII), Szczecin 1987, s. 5-135.

Silva Rerum. Pamiątki akademickie ze zbiorów Muzeum Uniwersytetu Jagiellońskiego, Katalog wystawy, Collegium Maius XII 1997-I 1998, autor wstępu do katalogu i biogramów A. Piskorz, przedm. S.Waltoś [Kraków] 1998.

Skierkowska E., Wyspiański artysta książki, red. A. Birkenmajer, wyd. 2, Wrocław 1970.

Smolik P., Książka Stanisława Wyspiańskiego, „Rzeczy Piękne”, R. 11, 1932, nr 1-12, s. 33-37.

Stanisław Wyspiański: dzieła malarskie, tekst S. Przybyszewski, T. Żuk Skarszewski, indeks oprac. S. Świerz, Bydgoszcz 1925. 
Szczerski A., Wzorce tożsamości. Recepcja sztuki brytyjskiej w Europie Środkowej około roku 1900, Kraków 2002.

Śliwińska M., Wyspiański. Dopóki starczy życia, Warszawa 2017.

Urban J., Muzeum Katedralne na Wawelu, „Muzealnictwo” 2008, nr 49, s. 114-131.

Wyspiański. Katalog wystawy dziet ze zbiorów Muzeum Narodowego w Krakowie, red. D. Godyń, M. Laskowska, Kraków 2017.

Wyspiański S., Dzieła zebrane, t. 16, vol. II: Kalendarz życia i twórczości 1 marca 1890 - ostatnie dni marca 1898 Stanisława Wyspiańskiego, oprac. M. Stokowa, Kraków 1982.

Zbijewska K., Orzeł w kurniku. Z życia Stanisława Wyspiańskiego, Warszawa 1980.

\section{Strony internetowe}

Katsushika Hokusai. The complete works. Lilies, https://www.katsushikahokusai.org/Lilies.htm [dostęp: 29.01.2018].

La plante et ses applications ornementales, https://bibliotheque-numerique.inha.fr/collection/ item/19965-la-plante-et-ses-applications-ornementales [dostęp: 25.04.2018].

Lilia cmentarna, http://cyfrowe.mnw.art.pl/dmuseion/docmetadata?id=11843 [dostęp: 28.04.2018]. 


\section{Anna Piskorz}

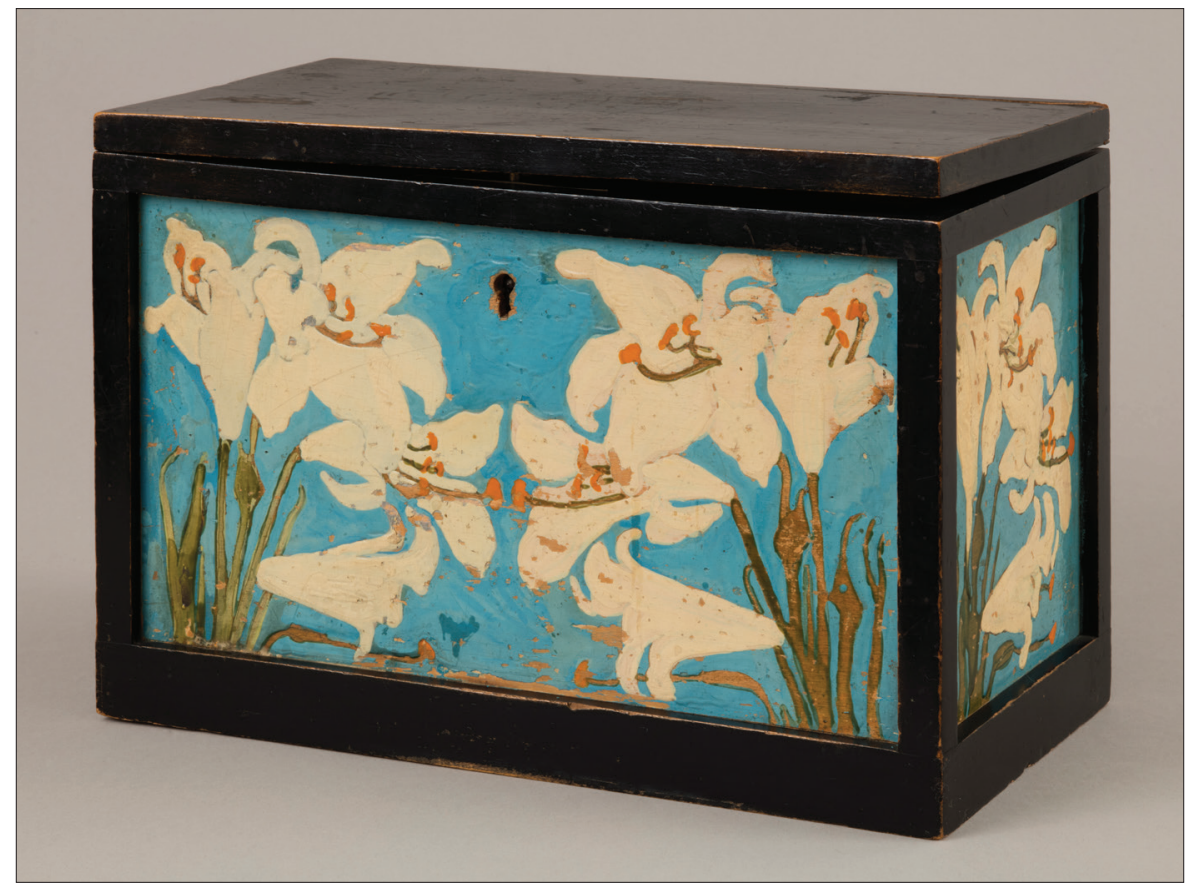

Il. I. Kaseta Stanisława Wyspiańskiego. Fot. G. Zygier

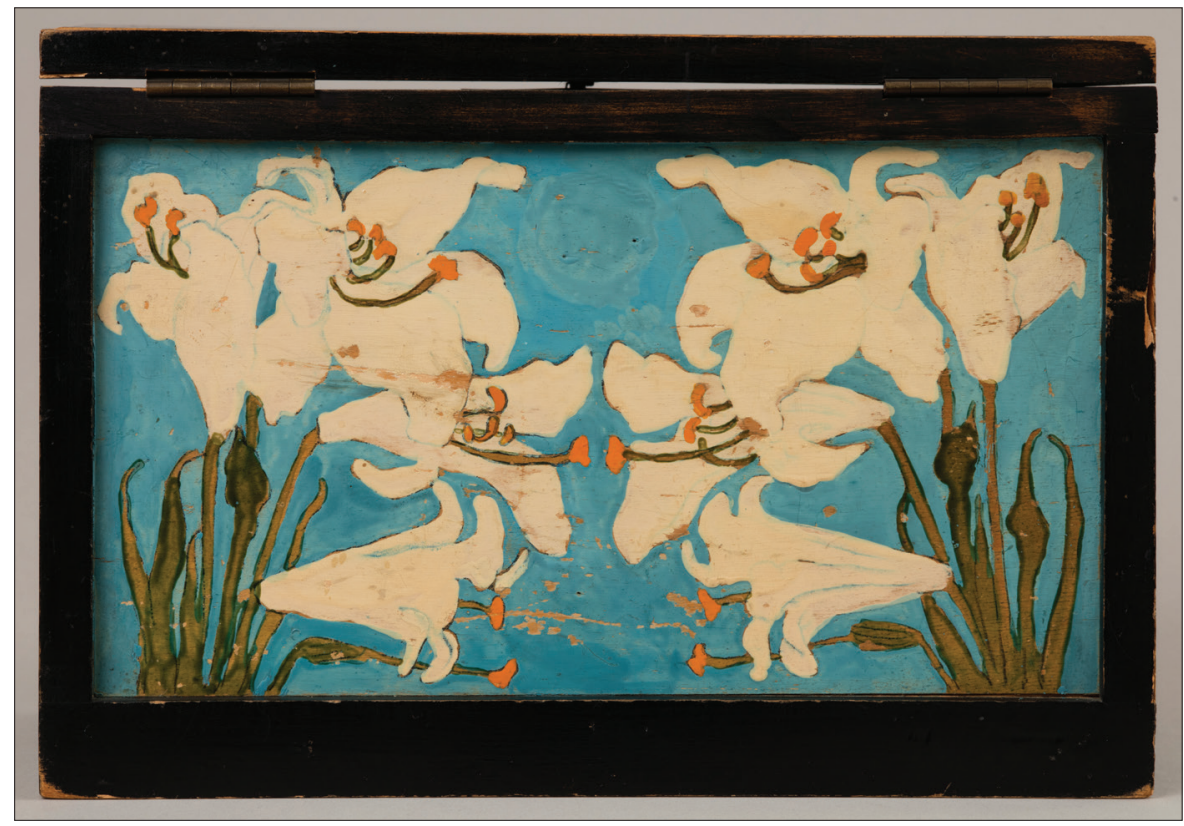

Il. II. Tylna ścianka kasety. Fot. G. Zygier 


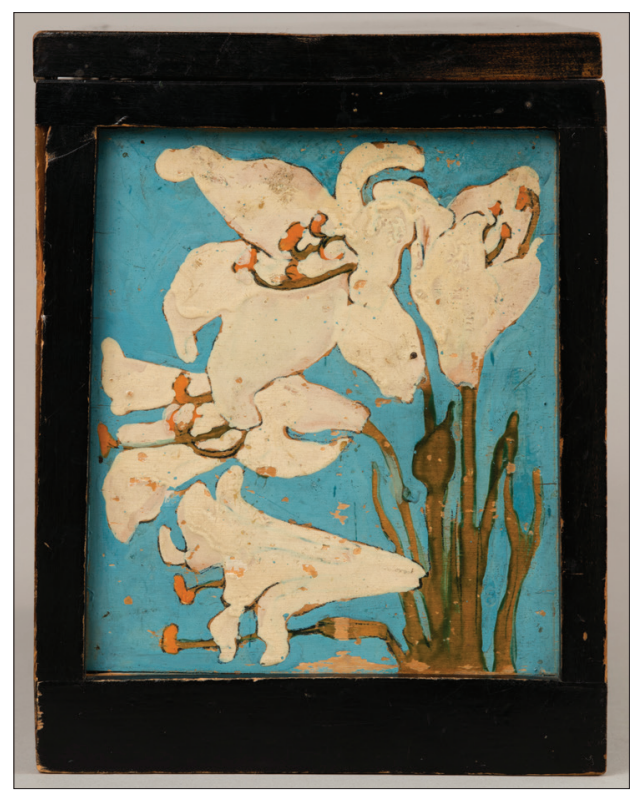

Il. III. Boczna ścianka kasety. Fot. G. Zygier

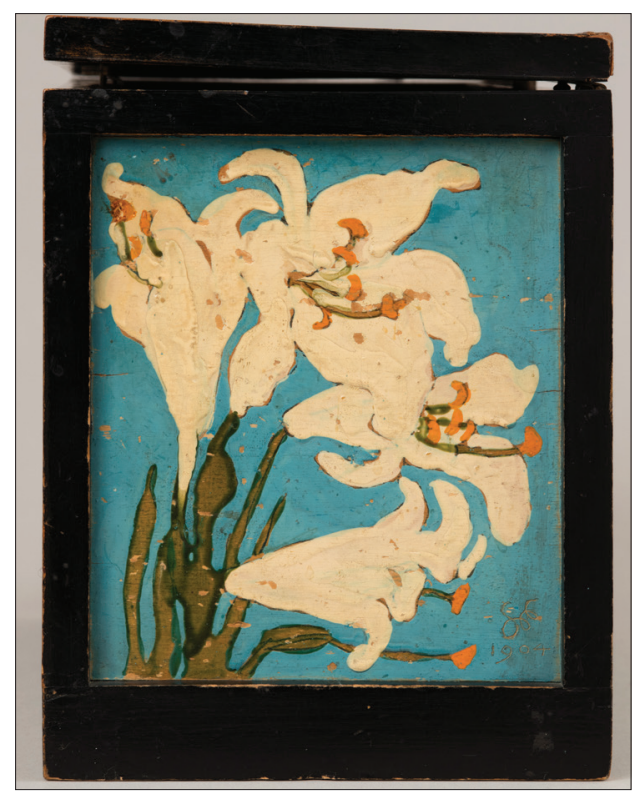

Il. IV. Boczna ścianka kasety z sygnaturą artysty i datą. Fot. G. Zygier

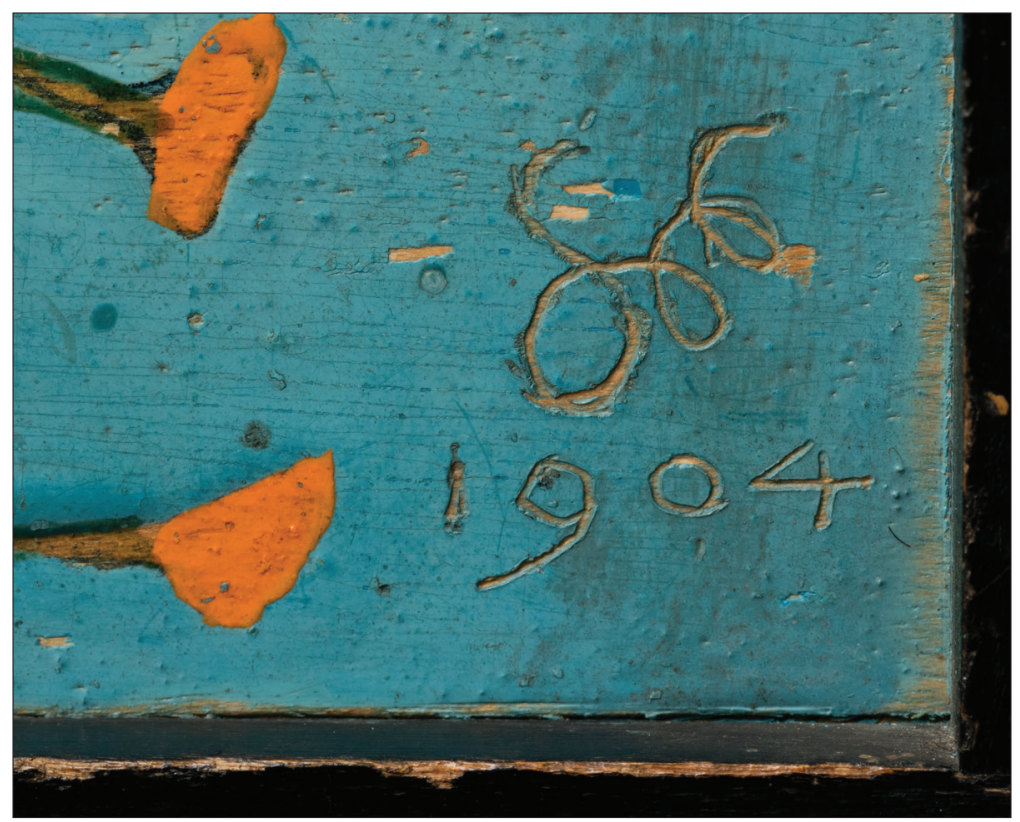

Il. V. Sygnatura i data. Fot. G. Zygier 